\title{
Research on Marxist Educational Innovation Based on Cultural Confidence
}

\author{
Ping Zhao \\ Nanyang Institute of Technology, Nanyang, Henan, 473000
}

Keywords: Marxist education; cultural confidence; innovation

\begin{abstract}
Marxist educational thought is the guiding ideology of China's educational development, and its historical development has constantly given it new content and meaning. Based on the new conditions, Comrade Xi Jinping comprehensively and profoundly elucidated educational innovation thought is a new development of Marxist educational thought and has created a new realm of Marxist educational thought, which has important guiding significance for accelerating the development of China's higher education.
\end{abstract}

\section{Introduction}

Marxist theoretical education is the basic task of higher education in China, and Marxist education innovation must also take China's higher education innovation as the basic coordinate. The innovation of higher education in China must be based on the functional development of higher education in China. The functional development of higher education constitutes the basic theme of higher education innovation in China. The functional structure of contemporary higher education is concentrated in the three dimensions of cultivating talents, inheriting civilizations and serving the society, thus forming the era coordinates of Marxist educational innovation. This paper takes the comprehensive improvement of the three major functions of higher education in China as the coordinate dimension to analyze the innovation of the times of Marxist education.

\section{The Definition of Marxist Educational Thought}

For the definition of Marxist educational thought, there is no consensus in the academic world. However, Marxist educational thought is the basic consensus that Marx and Engels pioneered and adhered to, applied and developed for the later generations of classic writers. According to this, we believe that Marxist educational thought is a series of viewpoints, thoughts and ideas about education that have been gradually formed and developed in the long-term revolutionary theoretical research and revolutionary practice by Marxist artists who are mainly represented by Marxist classic writers. The scientific theoretical system of doctrine. In the process of comprehensively revealing the general laws of the development of human society and profoundly explaining the scientific world view and methodology, the classic writers of Marxism have formed unique positions, viewpoints and methods for the major issues related to education, and constitute a very rich Marxist education. thought. These educational thoughts are a valuable asset in the history of human education. They are also an important ideological resource in today's society that enables us to examine educational phenomena at a higher level and solve educational problems, thus constantly improving and developing contemporary education. Therefore, accurately understanding and mastering Marxist educational thoughts and strengthening their in-depth research are of great significance to the development of educational science and the advancement of educational practice in the present era.

\section{New Development of Marxist Educational Thought}

Marxist educational thought is the guiding ideology of China's educational development, and the development of history has constantly given it new content and meaning. Comrade Jiang Zemin's comprehensive and profound elucidation of the idea of educational innovation based on new 
conditions is a new development of Marxist educational thought. An important clue to running through Marxist educational thought is about the all-round development of people. This idea is embodied in the critique of the one-sided development of the capitalist system and the general prediction of the ideal development of the future social person, which naturally implies the role of future education in the overall development of human beings. Although there is no specific systematic explanation of education in the work of Marne, the idea of real people in Marxism from the perspective of labor and social practice can be roughly applied to Marxist educational thoughts on the all-round development of human beings. The following is a summary: When the founder of Marxism examined the capitalist society, he found that the early capitalist "workshop industry turned workers into deformities, which suppressed the diverse production interests and production abilities of workers, and artificially cultivated the skills of workers. , "' is an automatic tool for some kind of local labor." And the capitalist large machine industry also makes workers merely an appendage to the machine; the machine "swallows all free activities of the body and spirit." "The capitalist exploitation system has caused workers to be abandoned and neglected not only by the bourgeoisie in terms of physical and intellectual aspects, but also in morality. This actually constitutes a kind of "social murder." The large industrial production of machines requires laborers to master Advanced technical knowledge is a person who is fully developed, but the capitalist production relationship turns the most active factor in productivity into a direct means of capital proliferation and a simple tool to create surplus value. This not only hinders the development of society. And progress, and the laborers are devastated both mentally and physically. It is in this understanding and in-depth analysis of the inherent contradictions of capitalism that Marne points out that the alienated capitalist society should be categorized and inevitable, Instead of the old bourgeois society with class and class opposition, it will be such a consortium, where the free development of everyone is the condition for the free development of all people. According to this, we can understand that human beings are comprehensive and free. The development is the essence and core of Marxist educational thought.

\section{Idea Innovation of Marxist Education in Colleges and Universities}

The core and essence of Marxist educational thought is the comprehensive and free development of human beings. When Marx and Engels talked about the inevitable demise of capitalism, he pointed out that "instead of the old society of the bourgeoisie with class and class opposition, it would be such a union, where the free development of everyone is the free development of all people. Condition"[1] 295. The "comprehensive and free development of man" put forward by Marxism is a concept with historical characteristics. In the process of using Marxism as the guiding ideology and striving to train socialist successors and builders, colleges and universities should serve "for whom to cultivate people", "what to train" and "how to train people" according to the characteristics of the new era. At the same time of this fundamental task, we will work hard to promote the comprehensive and free development of college students. Over the past 30 years of reform and opening up, colleges and universities have accumulated a lot of valuable theoretical and practical experience in strengthening and improving the ideological and political education of college students and striving to promote the popularization of Marxism in colleges and universities. This is the basis for the innovation of Marxist educational ideas in colleges and universities. Since the beginning of the new century, the globalization of the world economy has developed rapidly, and the exchanges between various cultures and countries of different civilizations have become more in-depth. In this process of cultural convergence and clash of civilizations, college students are vulnerable to some bad thoughts because of their limited discernment. Influence, lost political direction. In accordance with the new situation, colleges and universities should link social reality, strengthen college students' world outlook, outlook on life, values, and political outlook, and insist on using Marxist views to correctly interpret new problems arising in the times and social development; lead the universities with socialist core value systems. Thoughts, firmly establish the common ideal of socialism with Chinese characteristics among college students; use the profound humanistic spirit and academic connotation of colleges and universities to lure and encourage the 
healthy growth of college students, and build a "full-education, whole-course education, all-round education" The great moral education pattern of people [2]. In the process of education, colleges and universities should change the traditional educational thinking and establish an educational concept centered on the overall development of students. Colleges and universities should adhere to the different characteristics of college students' family background, growth environment, and their own abilities. They adhere to the educational philosophy of "teaching students according to their aptitude" and "having no education and teaching", so that each student can continue to learn and In practice, improve and improve their ideological and political qualities.

\section{Content Innovation of Marxist Education in Colleges and Universities}

Marxist education in colleges and universities, except for students of Marxist majors, the content of most students' learning is the ideological and political theory class. For a long time, most colleges and universities have the situation that teachers of ideological and political theory are difficult to teach, and students are unwilling to learn. The reasons are: On the one hand, some teachers only regard Marxist theory education as a simple ideological and political theory education, paying attention to Principles and theory, resulting in monotonous and boring teaching content, can not cause students' interest, which is not conducive to students' acceptance; on the other hand, many college students regard ideological and political theory courses as only necessary tasks, only concerned with the acquisition of credits. Instead of trying to understand the theoretical connotation of Marxism, we cannot understand the essence of methodology contained in the theory, and we do not know that learning Marxist theory can improve our own level of understanding and comprehensive quality.

Marxist education should attract college students with a scientific system. Educators should not emphasize the explanation of basic theories, but should enrich their own educational and teaching content. They should show the development of Marxist theory to college students, and tell college students that only by combining Marxist theory with Chinese reality can they guide our society. practice. Teachers should highlight the core position of Chinese Marxist theoretical education in the content of lectures. The basic content of Mao Zedong Thought, Deng Xiaoping Theory, the important thinking of the "Three Represents", and the Scientific Outlook on Development should be established with the founding of New China for more than 60 years. The achievements and experience gained, combined with the achievements and experiences of the reform and opening up over the past 30 years, have enabled university students to realize the tremendous achievements China has made in economic, cultural and educational fields under the guidance of the Chinese Marxist theory. Marx said: "As long as the theory can convince people to master the masses; and the theory can persuade people as long as it can be thoroughly." [1] 9 Through the study of the results of Chinese Marxist theory, the attraction and appeal of Marxist theory to college students can be enhanced. In the Marxist education, colleges and universities should also introduce some cases that are close to reality, so that the content of education is in line with reality, in line with society, and in line with international standards. It is necessary to use the latest Marxist theory to analyze the hot issues of contemporary society, analyze the topics that happen to college students, close to the thoughts, life and study of college students, and use Marxist theory to help college students solve some practical problems and narrow the distance between theory and students. Make students feel identity, and finally let college students accept and accept.

In addition, for the new problems that arise in the process of social development in China and the complicated and ever-changing international situation, the educators should guide the students to use the development perspective to analyze and let the students learn to look at the problems in the development with a developmental perspective. Development is the last word. In the teaching, it is also possible to appropriately add some comparative educational content, guide the students to learn in the comparison, and improve in the discussion, so that the socialist beliefs established can stand the test. 


\section{Conclusion}

Grasping the pulse of the times and solving practical problems is the basic mission of Marxist theoretical education and the basic principle of Marxist educational innovation. Marxist education innovation is a systematic project. This system engineering must take social life as the coordinate and must be connected with social practice, so as to find a breakthrough in Marxist education innovation. In short, Marxist educational innovation must pay attention to the social life of the people, achieve the organic unity of theory and practice, and solve the real problems as the mission of the times.

\section{References}

[1] Liang Shufa. Reflections on the theme of Marxist theoretical innovation in the new era [J]. Teaching and Research, 2011 (6).

[2] Zhang Jing. Promoting the popularization of Marxism is the mission and responsibility of theoretical innovation and discipline construction in college moral education [J]. Chinese Higher Education, 2010, (1): 18.

[3] Chen Chunyan, Dou Zhi. Current college students' thoughts on dynamics [J]. Education and career, 2011, (4).

[4] Qin Xueyuan. The development and innovation of Marxist theoretical education in colleges and universities [J]. Journal of Guangxi Teachers College: Philosophy and Social Sciences Edition, 2008, (4): 71. 